\title{
Enterprise financing decision-making under information asymmetry
}

\author{
Lin Tao
}

Office of Budget and Finance, Yibin University, Yibin, 644007, China

Keywords: information asymmetry; small and medium enterprise financing; informal finance; new pecking order theory

Abstract: in enterprise financing process, information asymmetry is a very outstanding problem influencing financing of small land medium enterprises. For China, information asymmetry existing in small land medium enterprises seriously affects defective, convenient and fast financing of such enterprises. Through theoretical discussion of financing decision-making and activities under information asymmetry of enterprises (especially small land medium enterprises), this paper analyzes various effects of information asymmetry on enterprise financing and then proposes the countermeasures and methods to solve enterprise financing problem under information asymmetry.

\section{Interpretation of enterprise financing theories}

American scholars Modigliani and Miller put forward such a view: under certain conditions, enterprises will not influence their total market value regardless of debt financing and equity capital financing. This is "MM theorem" honored as one of modern finance benchmarks. According to relevant theories of "MM theorem", in a perfect competition economy under information symmetry without tax revenue and transaction cost, enterprise value and its capital structure have no any correlation if there is no enterprise bankruptcy risk. Under such situation, enterprise value is mainly decided by enterprise physical assets, rather than enterprise capital financing mode. This means enterprise value will not be influenced and restricted by enterprise financing decision-making.

However, in reality, when enterprises carry out external financing, information asymmetry often occurs between enterprises and investors. Since investors do not completely know enterprise-related information and especially investors cannot master necessary information, they cannot make specific pr-judgment of financing project profitability. Thus, investors may turn investors to other enterprises or projects. It thus can be seen that under information asymmetry, enterprise financing decision-making or activity will to a large extent enterprise value. For an enterprise, raising the maximum funds with the lowest financing cost and then achieving shareholder value maximization has been the objective enterprises strive to pursue.

\section{Two main enterprise financing modes}

Under market economic conditions, there are mainly two enterprise financing modes, i.e. external financing and internal financing. Enterprises raise funds for their development through the two modes and create conditions for further development and growth. Next, this paper will introduce the two main financing modes and analyze their differences and similarities.

1. External financing

External financing is a process in which enterprises raise funds from other economic subjects through certain ways. In other words, in the financing process, enterprises absorb capital or savings of other economic subjects and transform them to their investment process. External investment can be roughly classified into three kinds: bank loan, stock issuance and enterprise bonds etc. Besides, business credit and financing lease among enterprises can be classified into the category of external financing. For a long term, enterprises' traditional financing mode is internal financing, but as enterprise technology continuous advances and the production scale continuously expands, it is hard for enterprises to meet capital need only through internal financing. Under such background, external financing gradually becomes the major way fort enterprises to gain various funds.

Although external financing is vital for enterprise development, all kinds of enterprises 
(especially small and medium enterprises) pay attention to applying external financing mode for enterprise capital operation. But, under realistic conditions, small and medium enterprises are still faced with many challenges under external financing environment. These challenges mainly include the following: firstly, the conditions under which commercial banks provide loans cannot completely adapt specific and realistic situations of small and medium enterprises. Except commercial banks, state-owned banks hold relatively positive attitude in raising funds for small and medium enterprises, but it is difficult to provide all kinds of fund services due to impacts of traditional thinking. Foreign banks are cautious and meticulous during providing loans for small and medium enterprises. For general Chinese small and medium enterprises, foreign banks will not provide risk loans for them. Secondly, all sorts of private financing still lack relevant laws and regulations. Since private lending institutions and enterprises grasp asymmetric information, some private capitals driven by high profit will flow into limited industries or sectors so that state macro-control cannot play a role to the largest extent. This restricts effects of macro-control and is to the disadvantage of industrial structure optimization, upgrade and credit structure adjustment. Thirdly, intermediary financing organizations have incomplete system. Currently, there are more than 2000 guarantee institutions for small and medium enterprises, and the number of accumulated enterprises guaranteed is as high as 190000 . But, accumulative amount guaranteed is only RMB 300 billion. This indicates guarantee institutions for small and medium enterprises do not give full play to their functions. It is necessary to further improve and perfect such institutions.

2. Internal financing

Internal financing theory develops from "MM theorem". Internal financing mainly refers to the funds generated by enterprises through operation activities. Internal financing is mainly composed of two parts: retained income and depreciation. To be more specific, enterprises continuously transform their savings (including retained profit, depreciation and normed beds etc,) into investment. For enterprise capital formation, internal financing has the features of primitiveness, autonomy, low cost and anti-risk and is one of traditional enterprise financing modes. It plays a vital role in enterprise development process.

Internal financing has its advantages. Since internal financing utilizes idle assets of an enterprise and does not involve change and transfer of enterprise fund ownership and control right, the enterprise does not need to pay any cost. Meanwhile, cash flow will not reduce and the enterprise need not repay the capital and interest. It is a low-cost and high-income financing mode. Especially at present when the acquisition cost is quite high, internal financing is very beneficial to small and medium enterprises. More importantly, since internal financing generally does not involve the relationship between the enterprise and the external, national laws have few regulations and limits. Generally, no compel examination and approval process is needed. Small and medium enterprises can flexibly carry out it as needed. This greatly improves financing efficiency.

\section{Information asymmetry, moral hazard and adverse selection of enterprise financing}

In enterprise financing process, investors and enterprises are involved mostly. The two form specific principal-agent relation. Such relation has many forms, including one-way and two-way forms. Under information asymmetry, investors and the enterprise master different information and resources. The enterprise clearly knows its state of operation, investment project and financed funds allocation risk. However, for investors, it is hard for them to exactly know such information. This results in information asymmetry between investors and the enterprise. Such information asymmetry will impose impacts on investors and enterprise activities, thus influencing financing activities. Generally, information asymmetry will generate different impacts in different stages before and after financing. Before the financing contract is signed, adverse selection in capital market can easily happen. After the financing contract is signed, moral hazard behaviors of the enterprise may happen. The existence of adverse selection and moral hazard has become the major restrictive factor of an enterprise to achieve optimal allocation of resources through financing.

1. Adverse selection before the financing contract is signed

"Adverse selection” is a very rich phrase in economics. Generally speaking, "adverse selection” 
refers to a phenomenon where under market economic conditions, inferior products expel superior products due to information asymmetry and the decrease in market value and then average quality of products drops. Adverse selection generated in enterprise financing is reflected in the following aspects: firstly, the enterprises which most probably cause harmful results of capital operation are the enterprises which utilize external financing most actively and strive for external financing most probably. Secondly, market participants (large organizations and listed companies etc.) who can easily gain information advantage through various means take advantage of drawbacks of security system for insider trading and manipulating the market. Thus, speculativeness and risks of securities market increase abnormally. For general investors without information advantage, they have to undertake relatively large risks in order to obtain expected market income. Such circumstance causes the investors with high risk preference "like a duck to water". Thus, adverse selection in capital market forms.

\section{Moral hazard after the financing contract is signed}

After an investor signs the contract with the enterprise, information asymmetry often results in moral hazard. "Moral hazard" mainly refers to the behaviors against others done by those engaged in economic activities while enhancing their own effectiveness to the largest extent. In other words, it is a selfish behavior in order to maximize his own utility when one party of the contract incompletely undertakes risk consequences. Moral hazard appearing in financing process means the information is symmetrical when the investor and the enterprise reach a contract (at least both the investor and the enterprise consider they master real information), but information asymmetry may occur when the contract enters specific implementation process. In such case, the enterprise owning private information can utilize the information advantage to take some selfish behaviors to maximize his its efficiency, while such behaviors will damage the investors; benefit to some extent. In principal-agent relation, moral hazard generally exists. Meanwhile, moral hazard is also the root cause of enterprise financing agent cost.

\section{Several suggestions on solving enterprise financing difficulty under information asymmetry}

The important function of financing for enterprise development is self-evident, but various problems such as adverse selection and moral hazard exist in financing process. How to solve enterprise financing difficulty under information asymmetry? It becomes an issue that vast investors and enterprises jointly concern. In existing market economic conditions, solving this difficulty with informal finance is undoubtedly a shortcut. This paper proposes the following suggestions according to relevant theories and specific actual situations:

1. To enhance informal finance control and make proper adjustment

We can know from relevant theoretical research that cheap credit policy carried out by the government will not reduce loan interest rate in informal finance, but increase it. Cheap credit policy will generate two completely opposite impacts on informal finance: 1) opportunity cost of informal sectors will greatly decline; 2) infringement behaviors of informal sectors will correspondingly rise. This is mainly because cheap credit policy carried out by the government attracts low-risk pursuers in informal sectors to informal financial sector. Thus, informal financial sector takes over loan transactions with high risks, which is to the disadvantage of it s own development. So, the government must carry out necessary control of cheap credit policy, and properly adjust some policies according to specific conditions.

2. To encourage implementation of normal informal financial activities

The state must actively encourage and support normal informal financial activities and provide conditions for smooth implementation of the activities. Institutionally, the state should provide guarantee for informal financial organizations, accept legality of their activities and incorporate them into national financial supervision system. This can effectively reduce negative effects of informal finance and guide it to develop at healthy and orderly track. Specifically, it is required to standardize and restrain activities of informal financial institutions legally and institutionally, and make sure them give play to their due functions. 
3. To correctly distinguish financial institutions and activities with different natures

Informal finance and illegal finance have material differences. It is required to make a difference between them. Although there is no specific law and regulation to confirm informal finance, these institutions may gain legal qualification in the near future through effective transformation and guidance by the state and government. Meanwhile, such financial activities play an important role in promoting development of small and medium enterprises. But, illegal finance is completely different from informal finance. Illegal finance is not accepted by laws and regulations. Besides, it will result in great damages to market economy and have no benefit for enterprise development. Therefore, it is required to make a difference between informal finance and illegal finance. It is required to standardize, guide and transform informal finance, confirm it legal under mature conditions and make sure it exerts its due functions in promoting enterprise development. it is required to firmly prohibit illegal finance and compress its survival space as far as possible.

In conclusion, under information asymmetry, enterprises (especially small and medium enterprises) will confront great difficulties in financing. Adverse selection and moral hazard will also occur in financing process of investors and enterprises due to information asymmetry. All these make it very hard for small and medium enterprises to formulate and carry out financing activities. So, to open up new financing paths for small and medium enterprises, it is required to make the best of informal finance, make it exert its largest functions and achieve effective financing objective of small and medium enterprises.

\section{References:}

[1] Lin Yifu, Development of small and medium financial institutions and financing of small and medium enterprises [J]. Economic Research, 2001,(1)

[2] Research group of People's Bank of China Changde Center Branch, Survey of rural private lending in Changde City [J]. Finance Reference, 2001,(8).

[3] Liu Minquan, Xu Zhong, Yu Jiantuo, informal finance in credit market [J]. World Economy, 2003,(7)

[4] [Indian] Gupta, Rensink, Financial liberalization and investment [M]. Beijing: Economic Science Press, 2010

[5] He Fan. Make informal finance return to normal track, China News, 2004-05-18

[6] Cao Liqun, Formation cause, feature and effect of Chinese rural private lending [J]. Chinas Rural Studies, 2101,(26) 